\title{
In-woods chipping: Possible evidence for allelochemical interaction of leachate generated from trembling aspen (Populus tremuloides Michx.) bark and wood waste
}

\author{
by Timothy S. S. Conlin ${ }^{1}$
}

\begin{abstract}
A portable delimber-debarker-chipper, designed for in-woods chipping operations, was used to produce waste bark and wood residue from winter-harvested tree-length trembling aspen logs. The residue was then utilized to create leachate, which was subsequently used to treat white spruce, lodgepole pine, paper birch, aspen and Calamagrostis canadensis seedlings grown in sand-filled pots. Treatment with the leachate significantly decreased height growth and shoot and root dry weights of all species relative to the control treatment. Root:shoot ratios of all tree species except lodgepole pine were increased significantly by application of leachate. The root:shoot ratios of treated $C$. canadensis were significantly increased during one season, but significantly reduced in the following season. The data indicated that leachate from aspen bark and wood residue contain allelochemical properties that could affect the regenerative capacity of aspen cutblocks harvested for in-woods chipping operations.
\end{abstract}

Key words: aspen, leachate, allelochemistry, Populus tremuloides, in-woods chipping

Une ébrancheuse-écorceuse-déchiqueteuse mobile, conçue pour les opérations de mise en copeaux en forêt, a été utilisée pour produire des résidus d'écorce et de bois provenant de troncs en longueur de peuplier faux-tremble récoltés au cours de l'hiver. Les résidus ont été par la suite utilisés pour créer un médium de percolation qui a été utilisé par la suite pour traiter des semis d'épinette blanche, de pin lodgepole, de bouleau à papier, de peuplier et de Calamagrostis canadensis cultivés dans des pots remplis de sable. Le traitement avec le médium a entraîné une diminution significative de la croissance en hauteur et du poids sec de la pousse et des racines de toutes les espèces par rapport au traitement témoin. Les ratios racines/pousse de toutes les espèces d'arbres à l'exception du pin lodgepole ont été augmentés de façon significative suite à l'application du médium. Les ratios racines/pousse des $C$. canadensis traités ont augmenté de façon significative au cours d'une saison, mais étaient significativement réduits la saison suivante. Les données indiquent que le médium obtenu à partir de l'écorce et des résidus de peuplier contient des éléments allélochimiques qui pourraient

Mots-clés : peuplier, percolation, allélochimie, Populus tremuloides, déchiquetage en forêt

\section{P̂̃troduction}

In British Columbia, the recent expansion in the use of aspen efopulus tremuloides Michx.) as a major source of wood Iftre, along with the regulated phase-out of beehive burners, fas led to increased generation of aspen mill waste. This g aste has the potential of creating large amounts of leachate Q food and leaves. Leachate generated from decked aspen \$ogs and waste bark and wood is toxic to aquatic organisms fGGoudey and Taylor 1992, Taylor 1994, Taylor et al. 1996); aqueous extracts of $P$. tremuloides leaves decreased the growth of several grass species (Younger et al. 1980); tissue oulture extracts of $P$. tremuloides demonstrated antimicrobial 3etivity (Mathes 1963) while leaf extracts of a closely relatFed species, $P$. tremula, showed anti-fungal properties (Olsen et al. 1971).

On-site chipping operations provide an opportunity for substantial reductions in harvesting and processing costs by reducing the amount of waste fibre hauled to the mill and by eliminating costs associated with waste residue disposal and the operation of a mill's wood room (Favreau 1992). However, on-site chipping operations also produce a large amount of bark and wood waste residue (approximately $167 \mathrm{~kg}$ of residue per $\mathrm{m}^{3}$ of aspen processed, North Peace Timber Ltd., Taylor, B.C.,

${ }^{1}$ Research Scientist, British Columbia Ministry of Forests Research Branch, PO Box 9519, Stn. Prov. Govt., Victoria, B.C. V8W 9C2. E-mail: Timothy.Conlin@ gems9.gov.bc.ca personal communication) which is left at the cutblock. By way of example, this would result in the creation of up to 58.3 tonnes of waste residue per $\mathrm{ha}^{-1}$ based on a high site index aspen stand containing $350 \mathrm{~m}^{3}$ $\mathrm{ha}^{1}$ in the Peace River area of British Columbia. This material is commonly deposited in a pile a short distance from the delimber-debarker-chipper (DDC) that is used to process trees into wood chips on-site.

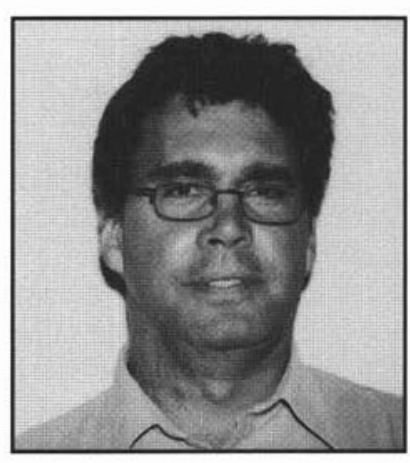

Timothy Conlin
Woodland managers interested in incorporating on-site DDCs into silvicultural prescriptions have speculated that redistribution of this bark and wood waste over the block might improve the productivity of the site.

However, given the evidence that aspen tissue can release toxic or allelochemical agents, it is possible that redistribution of wood and bark waste from on-site aspen chipping operations have the potential of producing large quantities of leachate which may delay or inhibit the subsequent regeneration of tree seedlings on an aspen cutblock. The purpose of this experiment was to determine if aspen leachate originating from residue generated by mobile chippers had a growth inhibiting effect upon white spruce (Picea glauca), lodgepole pine (Pinus contorta), paper birch (Betula papyrifera) or trembling aspen (Populus tremuloides) seedlings. Seedlings 
of Calamagrostis canadensis were also tested to examine the potential for using leachate as a biological control for this species.

\section{Methods}

\section{Plant Seedlings and Experimental Design}

Aspen seeds (Quality Seed Collections Ltd. - seedlots 9503 - Fort Nelson and 9504 - Chetwynd) were sown into sandfilled pots, allowed to germinate, and later thinned to one plant per pot. Paper birch (collected from the Fort Nelson Forest District courtesy of Dr. M. Carlson, Kalamlka Research Station, B.C. Forest Service) and C. canadensis (collected from km 524, Alaska highway, courtesy of Dr. R. Winder, Canadian Forest Service, Pacific Forestry Centre) seeds were pricked into sand-filled pots one week after germination. White spruce and lodgepole pine seeds (Surrey Seed Centre, seedlot numbers 33269 and 08992 respectively) were germinated in flats over a two-week period and then transplanted to sand-filled pots. Thawed 415B $2+0$ white spruce plugs (courtesy of Dave Cheyne, hardwood specialist, Fibreco Pulp Ltd.) were also planted in pots filled with sand.

Untreated sand from a local gardening supplier was used as a rooting medium to ameliorate uncontrollable stochastic responses that might have occurred if natural mineral soils were used. Two-gallon pots were used in all experiments. Although all plants were of the same age, there was some small variability in individual sizes. In order to ensure an equitable distribution of plant sizes and to ameliorate sampling bias, each plant was matched with another plant of similar size until two groups of potted plants were formed. The sample to be treated with leachate was then randomly selected using a coin toss. Seedlings within each treatment were watered twice daily $(250 \mathrm{ml}+250 \mathrm{ml})$ using tap water or aspen leachate applied directly to the soil. A $1 \%$ solution of 20-20-20 fertilizer was substituted for one regular watering every second day. The watering schedule was occasionally supplemented with 20 -minute misting periods on dry, hot days.

All plants were grown in a greenhouse environment during the summer growing season. With the exception of the white spruce plugs, each experiment with each species was repeated at least once in a subsequent year with a different batch of aspen residue. This was to ensure that seedling responses to the leachate treatments were not specific to aspen from a particular stand. Although the experiments were repeated with each species, environmental conditions could not be completely replicated and the first hot and dry summer of experimentation was followed by a cool and humid summer. As a consequence, aspen from the Chetwynd and Fort Nelson seed sources were merged into one group during the first year because of a drought-induced mortality event prior to treatment. This group was subsequently split into the control and leachate treatments. In the second year, the cool humid weather appeared to have contributed to the mortality rate observed in the seedlings during treatment.

Following harvest, each individual plant was divided into shoot and roots, dried at $80^{\circ} \mathrm{C}$ for 48 hours, and weighed. Spruce plug roots were further subdivided into the old plug root mass and new root growth, the latter based on succulent white roots growing outside the parameters of the plug root mass composed of peat and fibrous brown roots. The old plug roots were washed free of peat rooting media, and dried along with excised new roots and shoot material. Dry weights and root:shoot ratios of the control and treatment samples were compared using a two-sample Student's t-test.

\section{Production and Application of Leachate}

Leachate was produced by sprinkling 54 litres of tap water over a hopper filled with approximately $300 \mathrm{~kg}$ of aspen residue collected from North Peace Timber Ltd. at Taylor, B.C. The hopper was constructed from plywood and lined with a large plastic tarpaulin to prevent leakage at the seams. The residue originated from recent winter-logged aspen stems, which had their crowns removed prior to processing with a Peterson Portable Flail Delimber-Debarker-Chipper ${ }^{\mathrm{TM}}$. Prior to experimentation in each year, the old lot of residue was replaced with a load of new, fresh residue, which was then used to generate all batches of leachate during a growing season. The extract was collected in a carboy through a spigot at the bottom of the hopper within minutes of adding water. A fresh carboy was produced every three to four days, which was used for leachate treatment application to seedlings. Watering the treated plants with leachate commenced at the four- and twoleaf stages for aspen and birch respectively; after approximately three weeks for $C$. canadensis and the white spruce plugs; and after nine weeks for pine and spruce seedlings. Leachate was applied to all treated species over a six-week period for broadleaf seedlings and over eight weeks for conifer seedlings. Harvest occurred immediately after the cessation of leachate application for each species.

\section{Chemical Analysis}

Each time a 54-litre carboy of leachate was produced, a sample was frozen and stored until it could be chemically analyzed at the end of each growing season. Samples were analyzed using a Fisher Accumet $915 \mathrm{pH}$ meter with automatic temperature compensation and a Broadley James $\mathrm{pH}$ electrode and a Horiba DS-15 Conductivity Meter with automatic temperature compensation and a Horiba micro flow-through cell. A Waters High Pressure Liquid Chromatography system was utilized to determine the elemental concentration of $\mathrm{NH}_{4}, \mathrm{Cl}, \mathrm{NO}_{3}$, $\mathrm{PO}_{4}, \mathrm{SO}_{4}, \mathrm{Na}, \mathrm{Mg}$, and $\mathrm{Ca}$ ions while an ARL 3560 Inductively Coupled Plasma was used to determine the concentration of all other chemical ions. Aluminum concentrations in the leachate were not measured in the 1996 and 1997 treatment years. Mean $\mathrm{pH}$ and conductivity of the tap water before creation of leachate were 6.3 (s.e. 0.4) and 0.70 (s.e. 0.07) $\mathrm{mS}$ $\mathrm{cm}^{-1}$ respectively.

\section{Results}

The data for these experiments are summarized in Tables 1 , 2 and 3. Some mortality of tree species occurred during 1996 and 1997 and this is expressed by the final sample sizes. In every situation, shoot height was significantly reduced by the application of leachate. Root and shoot dry weights were also significantly reduced in all seedlings grown from seed. The leachate treatment did not effect the root:shoot ratios of $P$. contorta, while the root:shoot ratios of $P$. tremuloides and $B$. papyrifera were significantly increased by the leachate treatments. Mean root:shoot ratios of spruce were significantly higher than the control treatments only during the 1998 season. Root:shoot ratio responses of $C$. canadensis were less conclusive than those of the other species, with the ratio significantly higher in response to leachate in 1996, but significantly lower to 
Table 1. Means and standard errors for shoot height, root and shoot dry weight and root:shoot ratio for seedlings treated with aspen leachate during the summer of 1996; $n$ = sample size at end of treatment, $(N)=$ sample size at start of treatment. All treatment means are significantly different from controls using two-tailed t-test to determine the probability of a type I error.

\begin{tabular}{|c|c|c|c|c|c|c|c|c|c|}
\hline Species and treatment & $\mathrm{n}(\mathrm{N})$ & $\begin{array}{c}\text { shoot height } \\
(\mathrm{cm})\end{array}$ & p-value & $\begin{array}{c}\text { root dry } \\
\text { weight }(\mathrm{mg})\end{array}$ & $\mathrm{p}$-value & $\begin{array}{c}\text { shoot dry } \\
\text { weight }(\mathrm{mg})\end{array}$ & p-value & root:shoot & p-value \\
\hline \multicolumn{10}{|l|}{ Populus tremuloides } \\
\hline leachate & $16(20)$ & $1.7(0.1)$ & $<0.01$ & $37(4)$ & $<0.01$ & $35(4)$ & $<0.01$ & $0.96(0.07)$ & $<0.01$ \\
\hline no leachate & $14(20)$ & $8.3(0.7)$ & & $205(28)$ & & $354(35)$ & & $0.57(0.05)$ & \\
\hline \multicolumn{10}{|c|}{ Calamagrostis canadensis } \\
\hline leachate & $12(12)$ & $8.3(0.5)$ & $<0.01$ & $23(3)$ & $<0.01$ & $29 \quad(6)$ & $<0.01$ & $0.85(0.08)$ & $<0.01$ \\
\hline no leachate & $10(12)$ & $26.8(1.7)$ & & $430(60)$ & & 970 (149) & & $0.47(0.03)$ & \\
\hline
\end{tabular}

Table 2. Means and standard errors for shoot height, root and shoot dry weight and root:shoot ratio for seedlings treated with aspen leachate during the summer of 1997; $n=$ sample size at end of treatment, $(N)=$ sample size at start of treatment. All treatment means are significantly different from controls using two-tailed t-test to determine the probability of a type I error.

\begin{tabular}{|c|c|c|c|c|c|c|c|c|c|}
\hline$\underline{\text { Species and treatment }}$ & $\mathrm{n}(\mathrm{N})$ & $\begin{array}{l}\text { shoot height } \\
(\mathrm{cm})\end{array}$ & p-value & $\begin{array}{c}\text { root dry } \\
\text { weight }(\mathrm{mg})\end{array}$ & p-value & $\begin{array}{c}\text { shoot dry } \\
\text { weight }(\mathrm{mg})\end{array}$ & p-value & root:shoot & $\mathrm{p}$-value \\
\hline \multicolumn{10}{|l|}{$\begin{array}{l}\text { Populous tremuloides } \\
\text { (Fort Nelson seed) }\end{array}$} \\
\hline leachate & $10(12)$ & $2.5(0.3)$ & \multirow[t]{2}{*}{$<0.01$} & $37 \quad(4)$ & \multirow[t]{2}{*}{$<0.01$} & $76(8)$ & \multirow[t]{2}{*}{$<0.01$} & $0.51(0.04)$ & \multirow[t]{2}{*}{$<0.01$} \\
\hline no leachate & $12(12)$ & $9.1(1.4)$ & & 103 (15) & & 305 (49) & & $0.36(0.02)$ & \\
\hline \multicolumn{10}{|l|}{$\begin{array}{l}\text { Populous tremuloides } \\
\text { (Chetwynd seed) }\end{array}$} \\
\hline leachate & $7(12)$ & $2.0(2.9)$ & \multirow[t]{2}{*}{$<0.01$} & $24 \quad(4)$ & \multirow[t]{2}{*}{$<0.01$} & $48(6)$ & \multirow[t]{2}{*}{$<0.01$} & $0.49(0.06)$ & \multirow{2}{*}{$<0.01$} \\
\hline no leachate & $10(12)$ & $10.8(1.8)$ & & 102 (18) & & $354(63)$ & & $0.28(0.03)$ & \\
\hline \multicolumn{10}{|c|}{ Calamagrostis canadensis } \\
\hline leachate & $11(11)$ & $28.5(1.0)$ & \multirow[t]{2}{*}{$<0.01$} & $278(41)$ & \multirow[t]{2}{*}{$<0.01$} & $469(60)$ & \multirow[t]{2}{*}{$<0.01$} & $0.59(0.03)$ & \multirow[t]{5}{*}{$<0.01$} \\
\hline no leachate & $11(11)$ & $36.8(2.0)$ & & $1,280(135)$ & & $1,607(154)$ & & $0.78(0.04)$ & \\
\hline \multirow{3}{*}{\multicolumn{9}{|c|}{$\begin{array}{l}\text { Betula papyrifera } \\
\text { leachate } \\
\text { no leachate }\end{array}$}} & \\
\hline & & & & & & & & & \\
\hline & & & & & & & & & \\
\hline Pinus contorta & & & \multirow{3}{*}{0.048} & & \multirow{3}{*}{$<0.01$} & & \multirow{3}{*}{0.017} & & \multirow{3}{*}{0.79} \\
\hline leachate & $7(13)$ & $4.3(0.3)$ & & 61 (13) & & $106(43)$ & & $0.69(0.14)$ & \\
\hline no leachate & $8(13)$ & $6.3(0.7)$ & & 199 (31) & & $322(56)$ & & $0.64(0.04)$ & \\
\hline \multicolumn{10}{|l|}{ Picea glauca } \\
\hline leachate & $6(13)$ & $2.8(0.4)$ & \multirow[t]{2}{*}{$<0.01$} & $34 \quad(6)$ & \multirow[t]{2}{*}{$<0.01$} & 71 (17) & \multirow[t]{2}{*}{0.01} & $0.72(0.28)$ & \multirow[t]{2}{*}{0.52} \\
\hline no leachate & $7(13)$ & $6.2(0.7)$ & & $130 \quad(24)$ & & 255 (147) & & $0.52(0.16)$ & \\
\hline
\end{tabular}

Table 3. Means and standard errors for shoot height, root and shoot dry weight and root:shoot ratio for seedlings treated with aspen leachate during the summer of $1998 ; n=$ sample size at end of treatment, $(N)=$ sample size at start of treatment. All treatment means are significantly different from controls using two-tailed t-test to determine the probability of a type I error.

\begin{tabular}{|c|c|c|c|c|c|c|c|c|c|}
\hline Species and treatment & $\mathrm{n}(\mathrm{N})$ & $\begin{array}{l}\text { shoot height } \\
(\mathrm{cm})\end{array}$ & $\mathrm{p}$-value & $\begin{array}{c}\text { root dry } \\
\text { weight }(\mathrm{mg})\end{array}$ & $\mathrm{p}$-value & $\begin{array}{c}\text { shoot dry } \\
\text { weight }(\mathrm{mg})\end{array}$ & p-value & root:shoot & p-value \\
\hline \multicolumn{10}{|l|}{ Betula papyrifera } \\
\hline leachate & $18(18)$ & $1.9(0.2)$ & $<0.01$ & $55(8)$ & $<0.01$ & 76 (13) & $<0.01$ & $0.78(0.05)$ & $<0.01$ \\
\hline no leachate & $17(17)$ & $20.4(1.4)$ & & $422(49)$ & & $1351(155)$ & & $0.32(0.01)$ & \\
\hline \multicolumn{10}{|l|}{ Pinus contorta } \\
\hline leachate & $10(10)$ & $3.3(0.2)$ & $<0.01$ & $20(3)$ & $<0.01$ & $31 \quad(3)$ & $<0.01$ & $0.65(0.09)$ & 0.83 \\
\hline no leachate & $10(10)$ & $6.0(0.6)$ & & $54(4)$ & & $86(10)$ & & $0.67(0.05)$ & \\
\hline \multicolumn{10}{|l|}{ Picea glauca } \\
\hline leachate & $10(10)$ & $1.9(0.1)$ & $<0.01$ & 9 (1) & $<0.01$ & 12 (1) & $<0.01$ & $0.74(0.06)$ & $<0.01$ \\
\hline no leachate & $10(10)$ & $4.8(0.4)$ & & $19(2)$ & & $60 \quad(7)$ & & $0.33(0.02)$ & \\
\hline
\end{tabular}

this treatment in 1997. All of the Betula papyrifera treated with leachate in 1997 died before the end of treatment application.

Application of leachate to spruce seedling plugs during 1998 resulted in a significant reduction in the weight of new, white roots $(0.035 \mathrm{~g}$ [s.e. 0.005$]$ compared to the control treatment $(0.115 \mathrm{~g}$ [s.e. 0.017]). Shoot and brown root weights and root:shoot ratios were not significantly influenced by the leachate treatments. The spruce plugs did not flush during the 


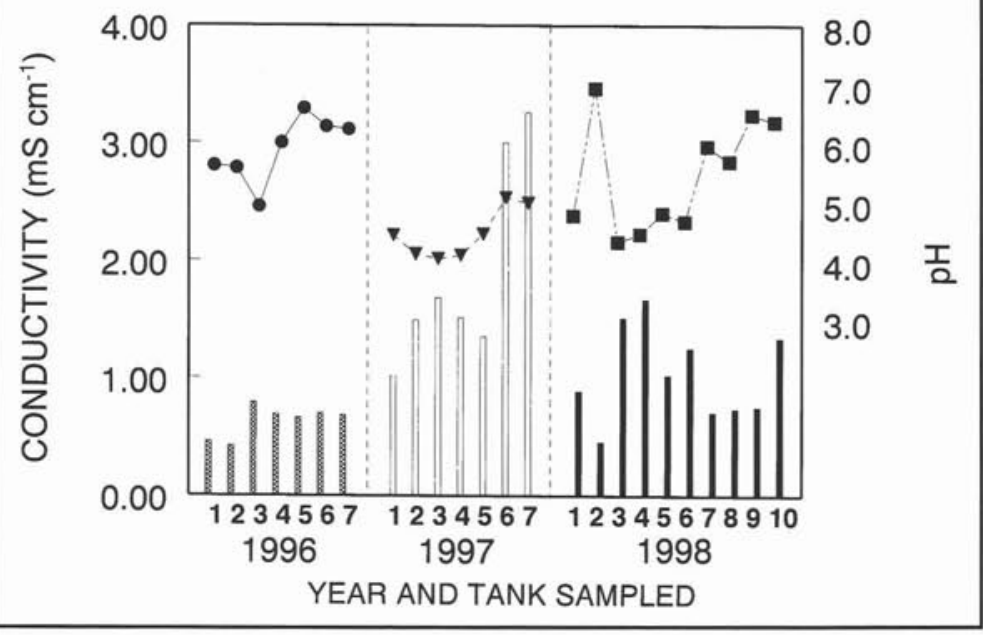

Fig. 1. Conductivity (bar graphs) and $\mathrm{pH}$ (plotted points) of each batch of leachate generated from aspen waste bark and

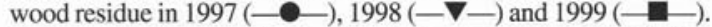
Each number between the $\mathrm{X}$-axis and the year represents a 54 -litre tank of leachate that was subsequently applied to the treated seedlings.
Table 4. Mean (s.e.) elemental concentrations of tap water used to create leachate and of the resulting leachate during 1998.

\begin{tabular}{|c|c|c|}
\hline Element & \multirow{2}{*}{$\begin{array}{c}\begin{array}{c}\text { Tap Water } \\
(\mathrm{n}=10)\end{array} \\
<0.01\end{array}$} & $\begin{array}{l}\text { Leachate } \\
(n=10)\end{array}$ \\
\hline $\mathrm{B} \quad\left(\mu \mathrm{g} \mathrm{I}^{-1}\right)$ & & $\begin{array}{ll}0.37 & (0.08)\end{array}$ \\
\hline $\mathrm{Ca}\left(\mu \mathrm{g} \mathrm{l}^{-1}\right)$ & $5.45(0.23)$ & $75.00(10.11)$ \\
\hline $\mathrm{Cl} \quad\left(\mu \mathrm{g} \mathrm{l}^{-1}\right)$ & $8.69(0.95)$ & $17.37 \quad(2.40)$ \\
\hline $\mathrm{K} \quad\left(\mu \mathrm{g} \mathrm{I}^{-1}\right)$ & $1.52(0.78)$ & 227.10 \\
\hline $\mathrm{Mg}\left(\mu \mathrm{g} \mathrm{l}^{-1}\right)$ & $1.37(0.08)$ & $39.19 \quad(6.13)$ \\
\hline $\mathrm{NH}_{4}\left(\mu \mathrm{g} \mathrm{l}^{-1}\right)$ & $0.46(0.08)$ & $0.22 \quad(0.11)$ \\
\hline $\mathrm{NO}_{3}\left(\mu \mathrm{g} \mathrm{l}^{-1}\right)$ & $0.14(0.04)$ & $<0.001$ \\
\hline $\mathrm{P} \quad\left(\mu \mathrm{g} \mathrm{l}^{-1}\right)$ & $0.04(0.01)$ & $28.71 \quad(6.77)$ \\
\hline $\mathrm{PO}_{4}\left(\mu \mathrm{g} \mathrm{l}^{-1}\right)$ & $0.20(0.0)$ & 76.17 (18.29) \\
\hline $\mathrm{SO}_{4}\left(\mu \mathrm{g}^{-1}\right)$ & $1.40(0.07)$ & $11.35 \quad(3.33)$ \\
\hline $\mathrm{Zn}\left(\mu \mathrm{g} \mathrm{l}^{-1}\right)$ & $0.13(0.02)$ & $1.69 \quad(0.33)$ \\
\hline Al $\quad\left(\mu \mathrm{g} \mathrm{l}^{-1}\right)$ & $0.69(0.20$ & $1.28 \quad(0.29)$ \\
\hline $\mathrm{Na} \quad\left(\mu \mathrm{g} \mathrm{l}^{-1}\right)$ & $1.32(0.06)$ & $3.30 \quad(0.23)$ \\
\hline $\mathrm{Mn}\left(\mathrm{ng} \mathrm{l}^{-1}\right)$ & $22.00(4.44)$ & $474.30(87.55)$ \\
\hline $\mathrm{Fe} \quad\left(\mathrm{ng} \mathrm{l}^{-1}\right)$ & $99.20(7.39)$ & $1198.40(146.44)$ \\
\hline $\mathrm{Cu} \quad\left(\mathrm{ng} \mathrm{l}^{-1}\right)$ & $4.22(0.70)$ & 31.10 (14.68) \\
\hline
\end{tabular}

experiment and it was therefore impossible to determine if the leachate had an influence on shoot growth.

The effect of leachate application was especially noticeable in the broadleaf tree species, with growth reduction making itself apparent within two weeks of leachate application. A noticeable reaction to leachate application occurred in the leaves of paper birch, which became dark green and took on a purple hue soon after treatments had begun. Calamagrostis canadensis plants treated with leachate appeared more yellow in colour than did grass in the control treatments.

Conductivity and $\mathrm{pH}$ of the samples drawn from the leachate are shown in Fig. 1. Elemental analysis of the leachate, along with its neutral to slightly acidic $\mathrm{pH}$ range, is shown in Table 4. Large increases in the concentrations of $\mathrm{K}$, $\mathrm{Ca}, \mathrm{P}, \mathrm{PO}_{4}, \mathrm{Mn}$ and $\mathrm{Fe}$ were observed in the leachate over that of the tap water, while decreases were observed in $\mathrm{NH}_{4}{ }^{+}$ levels and $\mathrm{NO}_{3}{ }^{-}$, which was almost completely removed from the leachate. Smaller increases in the concentrations of other elements were observed.

\section{Discussion}

The results demonstrated that leachate generated from aspen bark and wood waste significantly reduced growth rates of seedlings of several different tree species and $C$. canadensis. Also, during the 1997 experiment, leachate treatment of the birch resulted in the death of all seedlings in the sample population. However, it is unclear whether this one mortality event was a direct consequence of leachate application or due to a combination of stresses, including leachate application, which predisposed birch seedlings to mortality.

Populus deltoides was shown to exert an allelopathic influence on surrounding vegetation, which was attributed to the presence of large quantities of leachable phenolic acids found in the leaves and surrounding soil (Kohli 1998). Phenolic compounds can compose up to $10 \%$ of the bark and cambial tissue of aspen (Taylor et al. 1996). This suggests that aspen leachate had allelochemical properties (Jobidon and Thibault 1982) and that the potential impact of this allelochemistry should be considered when developing silvicultural plans for harvesting methods using in-woods chipping of aspen logs.

Chemical analysis of the aspen leachate indicated the presence of elements that, under the right conditions, may also induce a reduction in plant growth. Aluminum is known to have a toxic, growth- inhibiting effect upon plants, especially at lower $\mathrm{pH}$ concentrations (Mengel and Kirkby 1982). However, the high threshold concentration levels for $\mathrm{Al}$ toxicity in the species used in this experiment, along with $\mathrm{pH}$ values in the neutral to slightly acidic range, make it unlikely that $\mathrm{Al}$ toxicity contributed to the reduced growth of seedlings treated with leachate (Schaedle et al. 1989).

Boron, which was also found in the leachate, may promote micronutrient toxicity symptoms in trees and other plant species (Stone 1990). Neary et al. (1975) reported on red pine plantations that experienced boron toxicity when irrigated with waste water containing 0.51 to $0.91 \mathrm{mg} \mathrm{l}^{-1}$ boron. Although this concentration range was considered quite small, the authors discovered that the waste water was loading the irrigated soil with boron, resulting in a toxic accumulation of this 
element. Thus, there was the possibility that a steady application of aspen leachate may have loaded potted soils with toxic levels of boron. Boron can also be associated with saline soils, with many crop species showing a range of toxicity threshold values from 0.5 to $60 \mu \mathrm{g} \mathrm{l}^{-1}$ (Maas 1986).

Concentrations of other micronutrients in the leachate did not approach the levels required to induce toxic symptoms in white spruce (van den Driessche 1989) and were within the range of optimal concentrations observed in fertilizer solutions used for conifer seedling nursery stock (Donald 1991).

Another explanation for the reduced growth of seedlings treated with leachate was the possibility that they were experiencing a saline-induced response. Conductivity of the leachate was comparable to those found in irrigation water associated with soil salinity (Ulery and Ernst 1997) over the three growing seasons. However, the elemental composition of the leachate, with the exception of boron, is not characteristic of solutions associated with saline soils. Both $\mathrm{Na}$ and $\mathrm{Mg}$ concentrations were relatively low and $\mathrm{Ca}$ and $\mathrm{K}$ levels, while observed to be high, are not associated with salinity-related problems (Mengel and Kirkby 1982).

The dark green leaves observed in birch seedlings watered with leachate suggests phosphorus deficiency symptoms (Erdmann et al. 1979). Mengel and Kirkby (1982) also remarked on the general foliar symptoms of phosphorus deficiency that included darker green leaves with a red tinge. This suggests that aspen leachate might have interfered with the uptake of phosphorus by birch. Van den Driessche (1989) also showed that white spruce responded to low phosphorus by producing bright purple foliage. However, these symptoms were not observed in needles of white spruce exposed to leachate during the course of the experiments described in this manuscript, nor were visible foliar symptoms of phosphorus deficiency seen in the other species.

Although the data presented here suggested the possibility that leachate generated from aspen wood and bark waste had an allelochemical effect upon the species used in this experiment, the exact nature of this effect is uncertain. If the effect is related to organic compounds such as phenols, quantitative information is required about how these compounds affect plant growth, the microbiota responsible for their degradation, and their allelochemical threshold levels and residence time in forest soils. If, however, the allelochemistry is due to other factors, such as a micronutrient toxicity or salinity problems brought about by excessive amounts of a particular element in leachate, then foresters and managers must know of these properties before they can make informed decisions regarding in-woods chipping of aspen stands.

\section{Acknowledgements}

The funding for this work was provided by Forest Renewal British Columbia, project \# HQ96401RE. The author wishes to thank North Peace Timber Ltd., Taylor, B.C., for their cordial cooperation in providing the aspen bark and residue for this project and the help and cooperation of the Fort St. John
Forest District, B.C. Ministry of Forests. Advice and assistance was also provided by Dave Cheyne, former hardwood specialist with Fibreco Pulp Ltd., Taylor, B.C. Advice and support from Dr. Robert van den Driessche, Senior Tree Physiologist with the B.C. Ministry of Forests, is also gratefully acknowledged.

\section{References}

Donald, D.G.M. 1991. Nursery fertilization of conifer planting stock. In R. van den Driessche (ed.). Mineral nutrition of conifer seedlings. pp. 135-168. CRC Press, Boston.

Erdmann, G.G., F.T. Metzger and R.R. Oberg. 1979. Macronutrient deficiency symptoms in seedlings of four northern hardwoods. USDA Forest Service Gen. Tech. Rep. NC-53. 36 p.

Favreau, J. 1992. In-woods chipping: a comparative cost analysis. FERIC Tech. Rep. 105. 16 p.

Goudey, J.S. and B.R. Taylor. 1992. Toxicity of aspen wood leachate to aquatic life. Part I: Laboratory studies. Prepared for Environmental Protection Division, Northern Interior Region, B.C. Ministry of Environment. 49 p.

Jobidon, R. and J.R. Thibault. 1982. Allelopathic growth inhibition of nodulated and unnodulated Alnus crispa seedlings by Populus balsamifera. Amer. J. Bot. 69: 1213-1223.

Kohli, K.R. 1998. Allelopathic interactions in forestry systems. In K. Sassa (ed.). Environmental Forest Science: Proceedings of the IUFRO Division 8 Conference Environmental Forest Science, 19-23 October 1998, Kyoto University, Japan. pp. 269-283. Kluwer Academic Pub., Boston.

Maas, E.V. 1986. Salt tolerance of plants. Applied Agricultural Research 1: $12-26$.

Mathes, M.C. 1963. Antimicrobial substances from aspen tissue grown in vitro. Science 140: 1101-1102.

Mengel, K. and E.A. Kirkby. 1982. Principles of plant nutrition. International Potash Institute, Bern. 655 p.

Neary, D.G., G. Schneider and D.P. White. 1975. Boron toxicity in red pine following municipal waste water irrigation. Soil Sci. Soc. Amer. Porch. 39: 981-982.

Olsen, R.A., G. Odham and G. Lindeberg. 1971. Aromatic substances in leaves of Populus tremula as inhibitors of mycorrhizal fungi. Physiol. Plant. 25: 122-129.

Schaedle, M., F.C. Thornton, D.J. Raynal and H.B. Tepper. 1989. Response of tree seedlings to aluminum. Tree Physiology 5 : 337-356.

Stone, E.L. 1990. Boron deficiency and excess in forest trees: A review.

For. Ecol. Mangt. 37: 49-75.

Taylor, B.R. 1994. Toxicity of aspen wood leachate to aquatic life. Part II: Field study. Prepared for Environmental Protection Division, Northern Interior Region, B.C. Ministry of Environment. $69 \mathrm{p}$.

Taylor, B.R., J. S. Goudey and N. B. Carmichael. 1996. Toxicity of aspen wood leachate to aquatic life: laboratory studies. Environ. Toxicol. Chem. 15: 150-159.

Ulery, A.L. and F.F. Ernst. 1997. Sorghum response to saline industrial cooling water applied at three growth stages. Agron. J. 89: 392-396.

van den Driessche, R. 1989. Nutrient deficiency symptoms in container-grown Douglas-fir and white spruce seedlings. FRDA Rep. 100. 29 p.

Younger, P.D., R.G. Koch and L.A. Kapustka. 1980. Allelochemic interference by quaking aspen leaf litter on selected herbaceous species. Forest Sci. 26: 429-434. 